Plant Tissue Cult. \& Biotech. 29(2): 151-159, 2019 (December)

CBangladesh Assoc. for Plant Tissue Culture \& Biotechnology

\title{
In vitro Regeneration of Ginger (Zingiber officinale Roscoe)
}

\section{Naimur Rahman Sumon ${ }^{1}$, Tanjina Akhtar Banu, Sanjida Rahman Mollika ${ }^{1}$, Barna Goswami, Mousona Islam, Shahina Akter, Ripa Akter Sharmin ${ }^{1}$ and M. Salim Khan*}

Plant Tissue Culture Section, Bangladesh Council of Scientific and Industrial Research, Dhanmondi, Dhaka-1205, Bangladesh

Key words: Regeneration, Zingiber officinale, Rhizome buds, Shoot tips

\begin{abstract}
An efficient and reproducible in vitro regeneration protocol was established for two varieties of ginger (Z. officinale Roscoe) namely, BARI Ada-1 and Chinese ginger accession number SG876). In case of BARI Ada-1 best result was obtained on MS supplemented with $2.0 \mathrm{mg} / \mathrm{BAP}, 0.5 \mathrm{mg} / \mathrm{Kn}$ and $0.5 \mathrm{mg} / \mathrm{NAA}$. In this combination, $95 \%$ rhizome bud explants responded within $6-8$ days and mean number of shoots per explant was $8.79 \pm 0.42$. On the other hand, Chinese ginger showed best $(90 \%)$ shoot regeneration response from the same explants on the same medium and hormonal combinations but in exchange of $0.25 \mathrm{mg} / \mathrm{NAA}$. In this hormonal composition shoot initiation started within 7 - 8 days of culture and mean number of shoots/explant was $6.83 \pm 0.71$ after $24-27$ days of culture. Maximum root induction ( 90 and $80 \%$ ) was found on MS supplemented with $0.5 \mathrm{mg} / \mathrm{IBA}$ and $0.5 \mathrm{mg} / \mathrm{NAA}$ in case of BARI Ada- 1 and Chinese ginger, respectively. The in vitro regenerated plantlets were successfully transplanted into the soil after acclimatization.
\end{abstract}

\section{Introduction}

Ginger (Zingiber officinale Roscoe) is a rhizomatous monocotyledon belongs to Zingiberaceae (Kambaska and Santilata 2009). It is a well known spice, produced from the rhizome of the tropical herbaceous plant. It was discovered in China as early as $400 \mathrm{BC}$ and has a long history of medicinal application dating back to 2500 years in China and India (Bhargava et al. 2012).

It is widely used in manufacturing a number of food products like curry powder, certain curried meats, table sauces, confectionary and ginger ale. Fresh ginger contains

*Author for correspondence: <k2salim@yahoo.com>. 'Department of Botany, Jagannath University, Dhaka-1100, Bangladesh.

DOI: https://doi.org/10.3329/ptcb.v29i2.44504 
$80.9 \%$ moisture, $2.3 \%$ protein, $0.9 \%$ fat, $1.2 \%$ minerals, $2.4 \%$ fibers and $12.3 \%$ carbohydrates (Zadeh and Kor 2014). It has pharmacological applications including antitumor, antioxidant, anti-inflammatory, antiapoptotic, cytotoxic, anti-proliferative and antiplatelet activities (Shukla and Singh 2007).

The global production of ginger was 3.3 million tons in the year 2016 (FAO 2017). Bangladesh is now the eighth largest ginger producing country in the world and ranked third in terms of consuming of ginger globally (FAO 2017). During 2001/2002, national yield of ginger in Bangladesh per acre was only 56913 metric tons. The productivity trend has been increasing since 2003 - 2004 and in 2017 - 2018 productivity reached 83004 metric tons per acre. Growing area of ginger increased from 18533 acres of land in 2001 2002 to 25246 acres in 2017 - 2018 (BBS 2018). Major ginger producing areas of Bangladesh are Rangpur, Nilphamari, Tangail, Rangamati, Bandarban, Khagrachari and Chittagong district (Choudhury et al. 1998). Ginger is vegetatively propagated through the underground rhizomes but unfortunately, multiplication rate using conventional breeding is very low due to poor flowering and seed setting. Moreover risk of systematic infections by root knot nematodes, bacterial wilt from the propagules is very high (Kavyashree 2009) and the rhizomes are not available in the crop season (Lincy and Sasikumar 2010).

It is estimated that three-folds increase in rhizome production could be possible by effective control of diseases and pests (Hosoki and Sagawa 1977). So, an efficient in vitro regeneration protocol is considered to be the best to produce disease free plant propagules for the continuous supply of plantlets for commercial uses (Hamirah et al. 2010). Therefore, an attempt has been made to establish an efficient, reliable and reproducible in vitro regeneration protocol for Zingiber officinale Roscoe available in Bangladesh in order to help large scale clonal propagation with better survival rate.

\section{Materials and Methods}

Rhizomes of BARI Ada-1 (previous accession number was G001) were collected from BARI. Rhizomes of Chinese ginger accession number SG876 were collected from local supplier which are occasionally grown in Bangladesh. These were maintained in the garden of BCSIR, Dhaka.

Explants (rhizome buds and shoot tips) collected from the garden were washed thoroughly under running tap water and soaked in liquid detergent (Surf excel) for 20 min and then rinsed four to five times with distilled water. The explants were then pretreated with fungicide (Babystin) for $3.0 \mathrm{~min}$ and rinsed three times with distilled water. After transferring the explants in autoclaved flask, final surface sterilization was done with ethanol $(70 \% \mathrm{v} / \mathrm{N})$ for $30 \mathrm{sec}$ and $0.1 \% \mathrm{HgCl}_{2}$ for $9-10 \mathrm{~min}$ inside the laminar flow cabinet. During this period, the flask was agitated continuously. Then the explants were washed five times with sterilized distilled water. 
Rhizome bud and shoot tip explants were excised with the help of a pair of sterilized forceps and scalpel on a sterile Petri dish. The culture establishment and proliferation of shoot tip and rhizome bud explants and their subsequent plantlets production on MS with BAP, Kn, NAA and IAA (used singly or in combination). All in vitro grown cultures were maintained according to the protocol described by Banu et al. (2017). After three weeks, the explants showing the sign of initiation of multiple shoot regeneration were sub-cultured on the same fresh medium. When shoots were produced in adequate number, elongated shoots were separated and cultured in the rooting medium for root formation. The plantlets with sufficient root system were taken out from the culture vessels and cleaned the agar on root surface under running tap water. The plantlets were then transplanted to small pots containing sterilized soil for further development.

\section{Results and Discussion}

The regeneration experiments were mainly conducted using the rhizome bud and shoot tip explants from BARI Ada-1 and Chinese ginger. Rhizome buds and shoot tips are commonly used as explants for micropropagation of pathogen free propagules on a large scale (Lincy and Sasikumar 2010).

Sterilization of rhizome buds was done using $0.1 \% \mathrm{HgCl}_{2}$ solution for $10-20 \mathrm{~min}$ to establish aseptic cultures in ginger (Suma et al. 2008, Kambaska and Santilata 2009, Khatun et al. 2016), turmeric (Rahman et al. 2004, Bharalee et al. 2005) and black thorn (Rahman et al. 2005). Between the two explants, rhizome bud was found to be the most responsive in terms of percentage of shoot regeneration as well as the number of shoots per explant in both the varieties (Table 1).

In BARI Ada-1, best result (95\%) was found on MS with $2.0 \mathrm{mg} / \mathrm{BAP}, 0.5 \mathrm{mg} / \mathrm{Kn}$ and $0.5 \mathrm{mg} / \mathrm{NAA}$ from rhizome bud explants. In this combination, shoot initiation started within 6 - 8 days and mean number of shoots per explant was $8.79 \pm 0.42$ (Table 1). Response towards shoot induction, multiple shoot formation and elongation of shoots in case of rhizome buds are presented in Fig. 1 (A-C). On the other hand shoot tip explants of BARI Ada-1 showed highest mean number of shoots $(6.72 \pm 0.49)$ on MS with $2.0 \mathrm{mg} / \mathrm{BAP}, 0.5 \mathrm{mg} / \mathrm{Kn}$ and $0.25 \mathrm{mg} / \mathrm{NAA}$. Fig. 1 (D-F) shows the various stages of shoot regeneration from shoot tip explants of BARI Ada-1. Rhizome bud explants also produced higher mean number of shoots $(7.29 \pm 0.47)$ on this combination of BAP, Kn and NAA. Kambaska and Santilata (2009) reported that medium containing $2.0 \mathrm{mg} / \mathrm{BAP}$ and $0.5 \mathrm{mg} / \mathrm{NAA}$ showed best response for shoot multiplication (7.5 shoots per rhizome bud) from rhizome bud explants of ginger.

Khatun et al. (2003) found best response from shoot tip explants of ginger on MS with $2.5 \mathrm{mg} / 1 \mathrm{BAP}$ and $0.5 \mathrm{mg} / \mathrm{Kn}$. But in the present study, when different concentrations of BAP and $\mathrm{Kn}$ were applied to examine their effect on shoot multiplication adequate response was recorded in MS supplemented with $2.0 \mathrm{mg} / \mathrm{A}$ BAP 
and $0.5 \mathrm{mg} / \mathrm{Kn}$ from rhizome bud explants of BARI Ada- 1 . In this combination shoot tip explants produced comparatively lower mean number $(3.93 \pm 0.70)$ of shoots (Table 1$)$. Islam et al. (2004) observed that BA $(12.0 \mu \mathrm{M})$ and NAA $(0.3 \mu \mathrm{M})$ were suitable for the induction of in vitro micro-rhizomes in case of Curcuma longa. Hazare et al. (2005) reported that MS with $2.0 \mathrm{mg} / \mathrm{L} \mathrm{BAP}$ and $2.0 \mathrm{mg} / \mathrm{Kn}$ proved superior for shoot multiplication from rhizome bud explants of turmeric.

Table 1. Effect of different concentrations and combinations of BAP, Kn, NAA and IAA on shoot regeneration from rhizome buds and shoot tips of BARI Ada-1 and Chinese ginger.

\begin{tabular}{|c|c|c|c|c|c|c|c|c|}
\hline Varieties & Explants & $\begin{array}{c}\text { BAP } \\
(\mathrm{mg} \Lambda)\end{array}$ & $\begin{array}{c}\mathrm{Kn} \\
(\mathrm{mg} /)\end{array}$ & $\begin{array}{l}\text { NAA } \\
(\mathrm{mg} \Lambda)\end{array}$ & $\begin{array}{c}\text { IAA } \\
(\mathrm{mg} \Lambda)\end{array}$ & $\begin{array}{l}\text { \% of } \\
\text { responsive } \\
\text { explants }\end{array}$ & $\begin{array}{c}\text { Initiation } \\
\text { of shoots } \\
\text { (days) }\end{array}$ & $\begin{array}{c}\text { Mean no. of } \\
\text { shoots / } \\
\text { explant }( \pm S E)\end{array}$ \\
\hline \multirow{9}{*}{ BARI Ada-1 } & \multirow{6}{*}{$\begin{array}{c}\text { Rhizome } \\
\text { buds } \\
\text { (RB) }\end{array}$} & 3.0 & - & - & - & 80 & $7-8$ & $5.63 \pm 0.72$ \\
\hline & & 3.0 & - & 0.5 & - & 90 & $8-9$ & $5.94 \pm 0.73$ \\
\hline & & 2.0 & 0.5 & - & - & 85 & $8-10$ & $6.06 \pm 0.66$ \\
\hline & & 2.0 & 0.5 & 0.5 & - & 95 & $6-8$ & $8.79 \pm 0.42$ \\
\hline & & 2.0 & 0.5 & 0.25 & & 85 & $7-9$ & $7.29 \pm 0.47$ \\
\hline & & 2.0 & 0.5 & - & 0.25 & 80 & $8-9$ & $5.13 \pm 0.96$ \\
\hline & \multirow{4}{*}{$\begin{array}{c}\text { Shoot tips } \\
\text { (ST) }\end{array}$} & 3.0 & - & - & - & 80 & $7-9$ & $4.13 \pm 0.62$ \\
\hline & & 3.0 & - & 0.5 & - & 85 & $7-8$ & $4.94 \pm 0.90$ \\
\hline & & 2.0 & 0.5 & - & - & 75 & $10-11$ & $3.93 \pm 0.70$ \\
\hline \multirow{15}{*}{$\begin{array}{l}\text { Chinese } \\
\text { ginger }\end{array}$} & & 2.0 & 0.5 & 0.5 & - & 85 & $8-9$ & $5.53 \pm 0.72$ \\
\hline & \multirow{7}{*}{$\begin{array}{l}\text { Rhizome } \\
\text { buds (RB) }\end{array}$} & 2.0 & 0.5 & 0.25 & - & 90 & $7-9$ & $6.72 \pm 0.49$ \\
\hline & & 2.0 & 0.5 & - & 0.25 & 75 & $9-10$ & $4.40 \pm 0.51$ \\
\hline & & 4.0 & - & - & - & 80 & $8-9$ & $5.50 \pm 0.52$ \\
\hline & & 3.0 & - & 0.5 & - & 80 & $7-9$ & $5.44 \pm 0.51$ \\
\hline & & 2.0 & 0.5 & - & - & 75 & $8-10$ & $5.20 \pm 0.68$ \\
\hline & & 2.0 & 0.5 & 0.5 & - & 85 & $8-9$ & $5.82 \pm 0.62$ \\
\hline & & 2.0 & 0.5 & 0.25 & - & 90 & $7-8$ & $6.83 \pm 0.71$ \\
\hline & \multirow{7}{*}{$\begin{array}{c}\text { Shoot tips } \\
\text { (ST) }\end{array}$} & 2.0 & 0.5 & - & 0.25 & 80 & $8-10$ & $5.13 \pm 0.62$ \\
\hline & & 4.0 & - & - & - & 80 & $8-9$ & $5.25 \pm 0.45$ \\
\hline & & 3.0 & - & 0.5 & - & 75 & $8-9$ & $4.67 \pm 0.49$ \\
\hline & & 2.0 & 0.5 & - & - & 80 & $9-10$ & $4.19 \pm 0.40$ \\
\hline & & 2.0 & 0.5 & 0.5 & - & 80 & $8-9$ & $5.31 \pm 0.48$ \\
\hline & & 2.0 & 0.5 & 0.25 & - & 85 & $8-9$ & $5.88 \pm 0.70$ \\
\hline & & 2.0 & 0.5 & - & 0.25 & 75 & $8-10$ & $4.53 \pm 0.52$ \\
\hline
\end{tabular}


Some reports represented that increasing dose $(6.0$ - $8.0 \mathrm{mg} /)$ of BAP decreased the rate of shoot multiplication of ginger (Rout et al. 2001). In the present study similar results were observed. MS with different concentrations of BAP $(1.0-5.0 \mathrm{mg} \Lambda)$ were applied to show their effect on regeneration of shoots. Among these combinations, maximum mean number of shoots $(5.63 \pm 0.72)$ was observed from rhizome buds of BARI Ada- 1 on MS containing $3.0 \mathrm{mg} /$ BAP (Table 1). Higher concentration of BAP (5.0 mg $/$ ) decreased the rate of shoot multiplication. Naz et al. (2009) observed the similar types of results in turmeric.
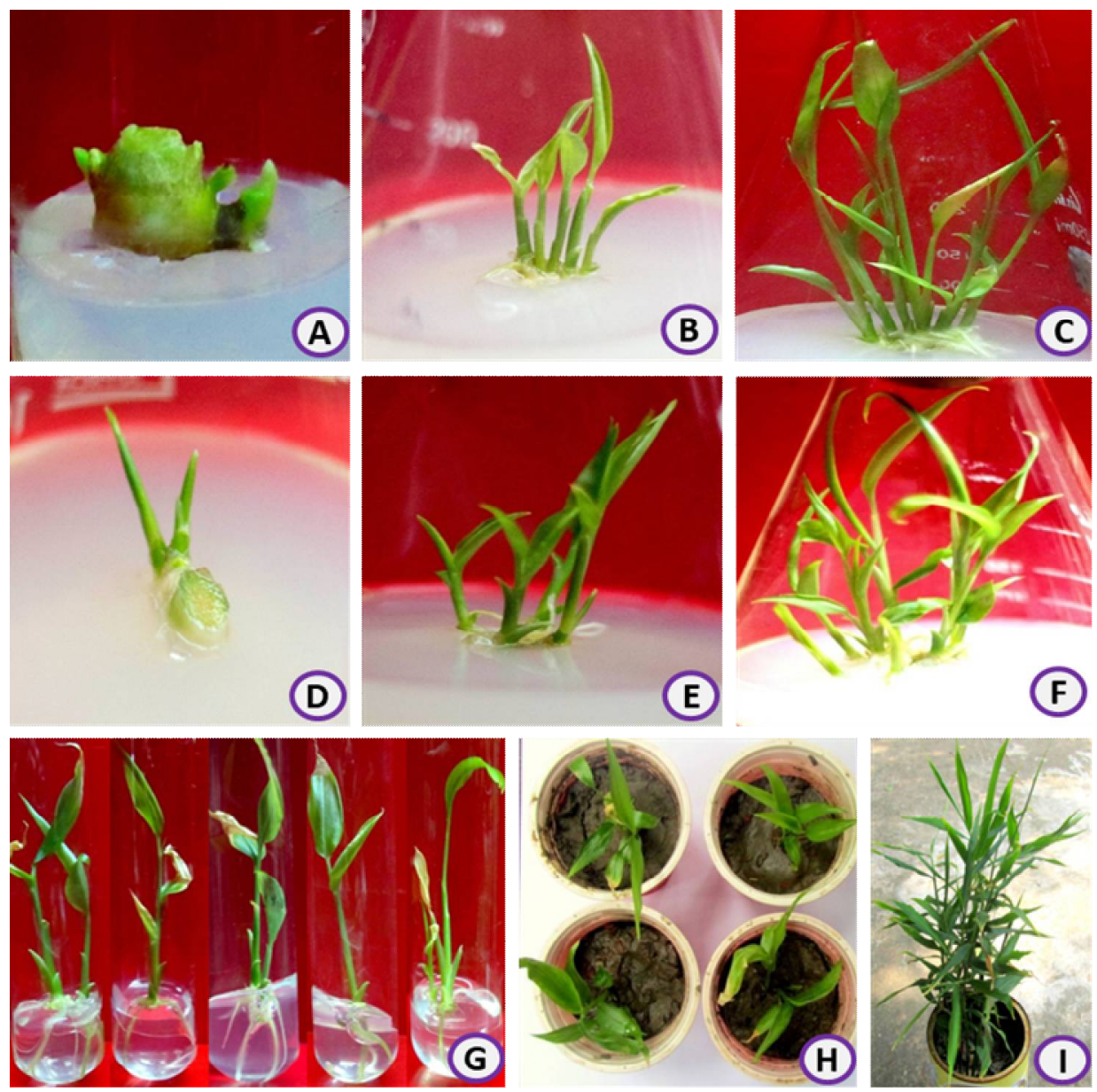

Fig. 1(A-I). Different stages of in vitro shoot regeneration, formation of roots and acclimatization of BARI Ada-1. A. Initiation of shoots from rhizome buds (RB). B. Multiple shoots formation from RB on same medium as mentioned in Fig. A; C. Elongation of multiple shoots from RB on same medium as mentioned in Fig. A. D. Initiation of shoots from shoot tips (ST). E. Multiple shoots formation from ST on same medium as mentioned in Fig. D. F. Elongation of multiple shoots on same medium and explants as mentioned in Fig. D; G. Initiation of roots from the base of excised regenerated shoots. H. Regenerated plantlets on soil in small plastic pots. I. Mature plantlets on large pot. 

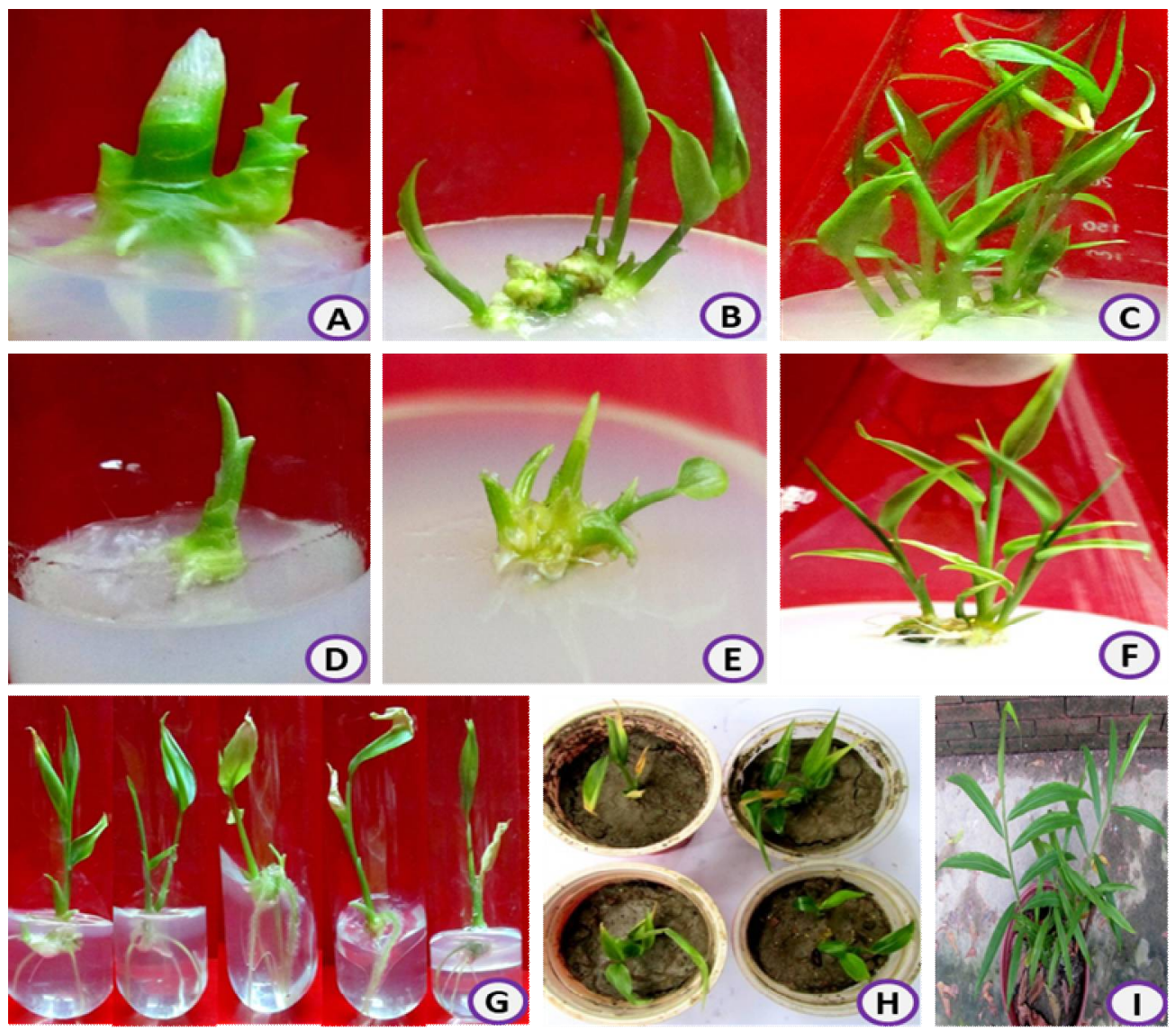

Fig. 2(A-I). Stages of in vitro regeneration of shoots, formation of roots and acclimatization of Chinese ginger. A. Initiation of shoots from rhizome buds (RB). B. Multiple shoots formation from RB on same medium as mentioned in Fig. A. C. Elongation of multiple shoots from RB on same medium as mentioned in Fig. A; D. Formation of shoots from shoot tips(ST) on same medium as mentioned in Fig. A. E. Multiple shoots formation from ST on same medium as mentioned in Fig. A. F. Elongated multiple shoots on same medium and explants as mentioned in Fig. A. G. Development of roots at the base of regenerated shoots. H. Regenerated plantlets on soil in small plastic pots. I. Mature plantlets on large pot.

In case of Chinese ginger, best response (90\%) was observed on MS supplemented with $2.0 \mathrm{mg} / \mathrm{BAP}, 0.5 \mathrm{mg} / \mathrm{Kn}$ and $0.25 \mathrm{mg} / \mathrm{NAA}$ from rhizome buds within 7 - 8 days. Mean number of shoots per explant was $6.83 \pm 0.71$ (Table 1). Different stages of shoot regeneration in case of rhizome buds are shown in Fig. 2A-C. Almost $85 \%$ of the shoot tip explants showed shoot regeneration on MS supplemented with $2.0 \mathrm{mg} \Lambda \mathrm{BAP}, 0.5 \mathrm{mg} \Lambda$ $\mathrm{Kn}$ and $0.25 \mathrm{mg} / \mathrm{NAA}$. About 8-9 days were required for initiation of multiple shoots and mean number of shoots per explant was $5.88 \pm 0.70$ (Table 1). Effects of shoot initiation, multiple shoot formation and elongation of shoots in case of shoot tips are presented in Fig. 2D-F. Mollika et al. (2011) reported that the highest percentage of 
responsive explants towards the regeneration of shoots was obtained in MS with $2.0 \mathrm{mg} /$ BAP, $0.5 \mathrm{mg} / \mathrm{Kn}$ and $0.2 \mathrm{mg} / \mathrm{NAA}$ in case of BARI Sarisha-11 and BARI Sarisha-16.

Beside this, MS supplemented with $4.0 \mathrm{mg} / \mathrm{BAP}$ showed better response towards shoot multiplication in both the explants of Chinese ginger (Table 1). Abbas et al. (2011) recorded the highest percentage of shoot multiplication on MS containing $4.5 \mathrm{mg} / \mathrm{BAP}$ for sprouting bud explants of ginger. BAP and NAA supplemented medium showed maximum response $(80 \%)$ of both the explants of Chinese ginger in MS with $3.0 \mathrm{mg} /$ BAP and $0.5 \mathrm{mg} /$ NAA (Table 1). Sathyagowri and Seran (2011), Yesmin et al. (2015) reported that $3.0 \mathrm{mg} / \mathrm{BAP}$ and $0.5 \mathrm{mg} / \mathrm{NAA}$ were best for shoot multiplication in ginger varieties.

It was observed that $90 \%$ shoots of BARI Ada- 1 were found to form roots on MS supplemented with $0.5 \mathrm{mg} / \mathrm{IBA}$ (Fig. 1G). On the other hand, MS with $0.5 \mathrm{mg} / \mathrm{NAA}$ were optimum for root induction in Chinese ginger where $80 \%$ shoots were found to form roots (Fig. 2G). Bhagyalakshmi and Singh (1988) stated that IBA is more effective compared to NAA for root formation in meristem culture of ginger. In contrary, NAA was more effective than IBA for induction of rooting in ginger (Kambaska and Santilata 2009). After sufficient development of roots, plantlets of both the varieties were successfully transplanted in small plastic pots (Figs $1 \mathrm{H}$ and $2 \mathrm{H}$ ). Three weeks after transplantation, when the regenerated plants were fully established in the small pots, then they were transferred to larger pots for further growth and development (Figs 1I and 2I). In here, the survival rate of the transplanted plantlets was found to be 95 and $85 \%$ in BARI Ada- 1 and Chinese ginger, respectively.

Based on the above discussion it may be concluded that regeneration protocol developed in the present investigation can successfully be used for large scale clonal propagation of Zingiber officinale. This will reduce the high importing cost of ginger and plays an important role in the economy of Bangladesh as well.

\section{References}

Abbas MS, Taha HS, Aly UI, El-Shabrawi HM and Gaber ESI (2011) In vitro propagation of ginger (Zingiber officinale Roscoe). J. Genet. Eng. Biotechnol. 9: 165-172.

Banu TA, Goswami B, Akter S, Islam M, Tanjin T, Habib A and Khan S (2017) High frequency in vitro regeneration of Gynura procumbens (Lour.) Merr. Plant Tissue Cult. \& Biotech. 27(2): 207216.

Bharalee RA, Das A and Kalita MC (2005) In vitro clonal propagation of Curcuma ceasia Roxb. and Curcuma zedoaria Rosc. from rhizome bud explants. J. Plant Biochem. Biot. 14: 61-63.

BBS (2018) Report on the productivity survey of ginger crop. Bangladesh Bureau of Statistical Division, Ministry of Planning, Govt. of the People's Repub. Bangladesh. pp. 1-110.

Bhagyalakshmi A and Singh NS (1988) Meristem culture and micropropagation of a variety of ginger (Zingiber officinale Rosc.) with a high yield of oleoresin. J. Hortic. Sci. 63: 321-327. 
Bhargava S, Dhabhai K, Batra A, Sharma A and Malhotra B (2012) Zingiber officinale: Chemical and phytochemical screening and evaluation of its antimicrobial activities. J. Chem. Pharm. Res. 4(1): 360-364.

Choudhury AK, Firoz ZA and Haque FME (1998) Performance of ginger legume intercropping at different spacing of ginger in hilly region. Bangladesh J. Agr. Res. 23(1): 133-142.

Food and Agriculture Organization (FAO) of the United Nations (2017) FAOSTAT. http:/www.fao.org/faostat/en/\#rankings/countries_by_commodity.

Hamirah MN, Sani HB, Boyce PC and Sim SL (2010). Micropropagation of red ginger (Zingiber montanum Koenig), a medicinal plant. Asia Pac. J. Mol. Biol. Biotechnol. 18(1): 127-130.

Hazare ST, Karnewar SD, Khedkad CD and Pawar VN (2005) In vitro micropropagation and regeneration of turmeric. J. Soils. Crop. 15: 304-307.

Hosoki T and Sagawa Y (1977) Clonal propagation of ginger (Z. officianale Rosc.) through tissue culture. J. Hortic. Sci. 12: 451-452.

Islam MA, Kloppstech K and Jacobsen J (2004) Efficient procedure for in vitro microrhizome induction in Curcuma longa (Zingiberaceae) a medicinal plant of tropical Asia. Plant Tiss. Cult. 14(2): 123-134.

Kambaska KB and Santilata S (2009). Effect of plant growth regulator on micropropagation of ginger (Zingiber officinale Rosc.) cv. Suprava and Suruchi. J. Agr. Tech. 5(2): 271-280.

Kavyashree R (2009). An efficient in vitro protocol for clonal multiplication of ginger var. Varada. Ind. J. Biotech. 8: 328-331.

Khatun A, Nasrin S and Hossain MT (2003) Large scale multiplication of ginger (Zingiber officinale Rosc.) from shoot tip culture. J. Biol. Sci. 3: 59-64.

Khatun M, Tanny T, Razzak A, Alam M, Uddin M, Amin M and Yesmin S (2016). Standardization of in vitro sterilization procedures for micropropagation of ginger (Zingiber officinale Rosc.). Int. J. Appl. Biol. Pharm. Tech. 7: 131-137.

Lincy A and Sasikumar B (2010) Enhanced adventitious shoot regeneration from aerial stem explants of ginger using TDZ and its histological studies. Turk. J. Bot. 34: 21-29.

Mollika SR, Sarker RH and Hoque MI (2011) In vitro plant regeneration in Brassica spp. Plant Tissue Cult. \& Biotech. 21(2): 127-134.

Naz S, Ilyas S, Javad S and Ali A (2009) In vitro clonal multiplication and acclimatization of different varieties of turmeric (Curcuma longa L.). Pak. J. Bot. 41: 2807-2816.

Rahman MM, Amin MN, Jahan HS and Ahmed R (2004) In vitro regeneration of plantlets of Curcuma longa Linn. A valuable spice plant in Bangladesh. Asian J. Plant Sci. 3: 306-309.

Rahman MM, Amin MN, Ahmed T, Ahmed S and Habib A (2005) In vitro rapid propagation of black thorn (Kaempferia galanga L.). A rare medicinal and aromatic plant of Bangladesh. J. Biol. Sci. 5: 300-304.

Rout GR, Palai SK, Samantaray S and Das P (2001) Effect of growth regulators and culture conditions on shoot multiplication and rhizome formation in ginger in vitro. In vitro Cell \& Dev. Biol. Plant 37: 814-819.

Sathyagowri S and Seran TH (2011) In vitro plant regeneration of ginger (Zingiber officinale Rosc.) with emphasis on initial culture establishment. Int. J. Med. Aromat. Plants. 1(3): 195-202.

Shukla Y and Singh M (2007). Cancer preventive properties of ginger. A brief review. Food Chem. Toxicol. 45: 683-690. 
Suma B, Keshavachandran R and Nybe EV (2008) Agrobacterium tumefaciens mediated transformation and regeneration of ginger (Zingiber officinale Rosc.). J. Trop. Agric. 46(1-2): 38-44.

Yesmin S, Hashem A, Khatun MM, Nasrin S, Tanny T and Islam MS (2015) In vitro clonal propagation of BARI Ada-1 (Zingiber officinale Rosc.). Jahangirnagar University J. Biol. Sci. 4(2): 53-57.

Zadeh JB and Kor NM (2014) Physiological and pharmaceutical effects of ginger (Zingiber officinale Roscoe) as a valuable medicinal plant. Euro. J. Exp. Bio. 4(1): 87-90.

(Manuscript received on 18 July, 2019; revised on 19 September, 2019) 